\title{
Design and Fabrication of Automated Countersinking Machine
}

\author{
Dr. M. K. Marichelvam ${ }^{1 *}$, Mr. K.Kandakodeeswaran ${ }^{1}$ \\ Department of Mechanical Engineering, Mepco Schlenk Engineering College, Sivakasi, Tamilnadu, India \\ *Corresponding Author: Dr. M. K. Marichelvam, Department of Mechanical Engineering, Mepco \\ Schlenk Engineering College, Sivakasi, Tamilnadu, India
}

\begin{abstract}
Countersinking is the tapering or beveling of the end of a hole with a conical cutter. Normally in most of the industries they are having a various types of special drilling machines for performing machine operations. Usually in drilling machine, the drilling operations are performed. Whereas counter sinking operation are also takes place but they need separate attachment. Every time counter sinking operation takes much time in normal machine. Therefore the productivity is also decreased. In order to reduce the human work and improve the productivity the counter sinking machine is fabricated. In this paper the piercing operation is also carried out by this fabricated counter sinking machine.
\end{abstract}

Keywords: Counter sinking machine, automatic machine, automated counter sinking machine.

\section{INTRODUCTION}

A countersink is a conical hole cut into a manufactured object, or the cutter used to cut such a hole. A common use is to allow the head of a countersunk bolt or screw, when placed in the hole to sit flush with or below the surface of the surrounding material. Material removal rate ranges from 1 to $15 \mathrm{~m}^{3} / \mathrm{min}$. Machining time will be ranges from 5 to 10 seconds. In bearing manufacture, the countersinking plays an important role. A countersink may also be used to remove the burr left from a drilling or tapping operation thereby improving the finish of the product and removing any hazardous sharp edges.

The basic geometry of a countersink (cutter) inherently can be applied to the plunging applications (axial feed only) and also to other milling applications (sideways traversal). Therefore countersinks overlap in form, function, and sometimes name with chamfering end mills. Regardless of the name given to the cutter, the surface being generated may be a conical chamfer (plunging applications) or a bevelled corner for the intersection of two planes (traversing applications).

Schwartz and Arthur A (1942) discussed about the construction of countersink drilling machine. In a countersink drilling machine, a frame, a drilling spindle rotatable mounted upon frame and adapted to move axially thereon, means for rotating spindle, a tubular member slidably mounted upon spindle and having an end portion adjacent the cutter end of spindle for contacting the work piece to be countersunk, a thrust collar integral with tubular member, a second thrust collar integral with spindle, a rocker arm pivotally mounted upon frame and having a moving end portion connected to link in such manner as to be adapted to move spindle and tubular member axially, spring means operatively connecting spindle and tubular member in such manner as to normally urge the cutter end of spindle to extend beyond the work piece contacting end of tubular member, spring means acting between frame and tubular member in such manner as to resiliently urge the latter to move toward the work piece, means associated with rocker arm for actuation of the latter to withdraw tubular member and spindle from work piece contacting position against the action of springs, and additional spring means operatively associated with rocker arm in such manner as to substantially balance the weight of the actuating elements of the device about the pivotal mounting of rocker arm upon frame.

Johnston and Harry M (1998) discussed about the countersunk cutter. In a countersink drilling machine, a countersink cutter mounted upon a spindle for countersinking an opening drilled through the work piece to be countersunk, a work piece supporting plate adapted to support said work piece under said cutter, a pilot pin slidably mounted within said supporting plate and spring pressed so as to be adapted to project upwardly beyond the plane of said work piece supporting plate when free to do 
so and adapted to project itself into the drilled opening of said work piece when the latter is moved into proper position under said countersink cutter.

Lance Nelson (2007) discussed about the spring loaded tool with floating depth control for countersinking holes. A floating tool-bit depth controlling nose piece for a spring loaded tool holder is used to countersink holes of equal size when the height of the work piece material changes. The floating tool-bit depth controlling nosepiece, driven by a CNC machine, is rigidly coupled to the floating portion of the tool holding element. The floating depth controlling nose piece has a bearing on the end to allow an area of the nosepiece to stop rotating when the nosepiece is pressed against the work-piece surface. Since the area of the nosepiece that comes into contact with the work-piece is no longer spinning in relationship with the work-piece, the possibility of scratching the work-piece surface is reduced. Additionally, the nosepiece has cut-outs therein to expel machined chips during countersinking of holes.

In all the above literatures, the piercing operation cannot be taken place with the countersinking machine. This will require high human work and give less productivity. So in order to reduce the human work and improve the productivity the counter sinking machine is fabricated. In this paper the piercing operation is also carried out by this fabricated counter sinking machine.

The objective of this machine is to

- Eliminate the transportation time for transferring the work piece from hole piercing machine to countersinking machine.

- To fully automate the countersinking process.

- Reduce the difficulties during countersinking process.

- Increase the productivity.

- Reduce the human error and efforts.

\section{Design Calculations OF THE COMPONENTS}

The components used in the counter sinking machine are

- Design of Journal bearing

- Design of Worm gear

- Design of Cylinder holder

- Design of spring

- Design of Cylinder actuation pressure

- Design of stopper fixture

\subsection{Design of Journal Bearing}

$\mathrm{D}=30 \mathrm{~mm}, \quad \mathrm{~N}=900 \mathrm{rpm}$

Where, $\mathrm{D}=$ Diameter of bearing, $\quad \mathrm{N}=$ Speed

\section{Step 1: Find L/D ratio}

From PSG data book, Page no. 7.31,

$$
\begin{aligned}
& \mathrm{L} / \mathrm{D}=2.5 \\
& \mathrm{P}=1.8 \mathrm{kgf} / \mathrm{cm}^{2}
\end{aligned}
$$

\section{Step 2: Find the load on bearing}

$$
\begin{aligned}
& \mathrm{P}=\mathrm{W} / \mathrm{LD} \\
& 0.18=\mathrm{W} /(75 \times 30) \\
& \mathrm{W}=505 \mathrm{~N}
\end{aligned}
$$

\section{Step 3: Find the value of $Z$}

From PSG data book, Page no. 7.31, 


$$
\begin{aligned}
& \mathrm{ZN} / \mathrm{P}=1522.3 \\
& (\mathrm{Z} \times 900) / 1.8=1522.3 \\
& \mathrm{Z}=2.85 \text { centipoise }
\end{aligned}
$$

\section{Step 4: Find the co efficient of friction}

$$
\begin{aligned}
\mu & =\left(\left(33.25 / 10^{10}\right) \times(\mathrm{ZN} / \mathrm{p}) \times(\mathrm{D} / \mathrm{c})\right)+\mathrm{k} \\
& =\left(\left(33.25 / 10^{10}\right) \times 1522.3 \times(30 / 0.15)\right)+0.002 \\
\mu & =0.0035
\end{aligned}
$$

\section{Step 5: Find heat generated}

$$
\begin{aligned}
\mathrm{H}_{\mathrm{g}} & =\mu \times \mathrm{W} \times \mathrm{v} \\
& =0.0035 \times 505 \times((\pi \times 0.03 \times 900) / 60) \\
& =2.35 \mathrm{~W}
\end{aligned}
$$

\section{Step 6: Find heat dissipated}

$$
\mathrm{H}_{\mathrm{d}}=\left((\Delta \mathrm{t}+18)^{2} \times \mathrm{LD}\right) / \mathrm{K}
$$

From data book, oil temperature is $90^{\circ} \mathrm{C}$.

But, room temperature is $30^{\circ} \mathrm{C}$.

$$
\begin{aligned}
& \Delta \mathrm{t}=90-30=60 \\
& \mathrm{H}_{\mathrm{d}}=\left((70+18)^{2} \times 0.075 \times 0.03\right) / 0.585 \\
& \mathrm{H}_{\mathrm{d}}=35.56 \mathrm{~W}
\end{aligned}
$$

Here, $\mathrm{H}_{\mathrm{g}}<\mathrm{H}_{\mathrm{d}}$

Hence, the artificial cooling is not provided.

\subsection{Design of Worm Gear Drive}

Gear ratio, $\mathrm{i}=20, \quad$ Speed of worm, $\mathrm{N}=1200 \mathrm{rpm}$

Assume Power $=1 \mathrm{KW}$

\section{Step 1: Selection of material}

From PSG data book, Page no. 8.45,

For worm, steel is selected.

For wheel, CI grade 35 is selected.

\section{Step 2: Calculation of number of stats}

From PSG data book, Page no. 8.46,

$$
\mathrm{Z}=3 \quad(\eta=0.8-0.92)
$$

\section{Step 3: Calculation of twisting moment}

$$
\begin{gathered}
{\left[\mathrm{M}_{\mathrm{t}}\right]=\mathrm{M}_{\mathrm{t}} \times \mathrm{K}_{\mathrm{d}} \times \mathrm{K}} \\
\mathrm{K}_{\mathrm{d}} \times \mathrm{K}=1 \\
\mathrm{M}_{\mathrm{t}}=(60 \mathrm{P} / 2 \pi \mathrm{N}) \\
=\left(60 \times 1 \times 10^{3}\right) /(2 \times \pi \times 60) \\
=159.15 \times 10^{3} \mathrm{Nmm} \\
{\left[\mathrm{M}_{\mathrm{t}}\right]=159.15 \times 10^{3} \mathrm{Nmm}}
\end{gathered}
$$

\section{Step 4: Calculation of compressive stress}

From PSG data book, Page no. 8.45,

$$
\left[\Sigma_{\mathrm{c}}\right]=159 \mathrm{~N} / \mathrm{Mm}^{2}
$$




\section{Step 5: Calculation of bending stress}

From PSG data book, Page no. 8.45,

$$
\left[\sigma_{b}\right]=30 \mathrm{~N} / \mathrm{mm}^{2}
$$

\section{Step 6: Calculation of centre distance}

From PSG data book, Page no. 8.44,

$$
\begin{aligned}
& \mathrm{a}=((\mathrm{Z} / \mathrm{q})+1) \sqrt[3]{\left(\left[55,0 /\left(\left(\frac{\mathrm{z}}{q}\right) \times\left[\sigma_{\mathrm{c}}\right]\right]^{2} \times\left(\left[\mathrm{M}_{\mathrm{t}}\right] / 10\right)\right.\right.} \\
& \mathrm{Z}=\mathrm{i} \times \mathrm{z}=20 \times 3=60 \\
& \quad \text { Initially, } \mathrm{q}=11 \\
& \mathrm{a}=((60 / 11)+1) \times \sqrt[3]{\left(\left[540 /\left(\left(\frac{60}{11}\right) \times[159]\right] 2 \times([159.15 \times 103] / 10)\right.\right.}
\end{aligned}
$$

\section{Step 7: Calculation of module}

From PSG data book, Page no. 8.43,

$$
\begin{array}{rl} 
& \mathrm{m}_{\mathrm{x}}=\frac{2 a}{q+z+2 x} \\
= & \frac{2 \times 118.17}{11+60+0} \\
= & 3.32 \\
\mathrm{~m}_{\mathrm{x}}=5 & 5
\end{array}
$$

\section{Step 8: Revision of centre distance}

From PSG data book, Page no. 8.43,

$$
\begin{aligned}
& a=0.5 \mathrm{~m}_{x}(q+z+2 x) \\
& a=0.5 \times 5 \times(11+60) \\
& a=152 \mathrm{~mm}
\end{aligned}
$$

\section{Step 9: Revision of twisting moment}

$$
\left[\mathrm{M}_{\mathrm{t}}\right]=159.15 \times 10^{3} \mathrm{Nmm}
$$

\section{Step 10: Check for compressive stress}

From PSG data book, Page no. 8.44,

$$
\begin{aligned}
& \sigma_{\mathrm{c}}=\frac{540}{(\mathrm{z} / q)} \times \sqrt{\left(\frac{\left(\frac{z}{q}\right)+1}{a}\right)^{3} \times([\mathrm{Mt}] / 10)} \\
& \sigma_{\mathrm{c}}=\frac{540}{(60 / 11)} \times \sqrt{\left.\frac{\left(\frac{60}{11}\right)+1}{152}\right)^{3} \times([159.15 \times 103] / 10)} \\
& \sigma_{\mathrm{c}}=123.6 \mathrm{~N} / \mathrm{mm}^{2}
\end{aligned}
$$

Here, induced $\sigma_{\mathrm{c}}<$ allowable $\left[\sigma_{\mathrm{c}}\right]$

Design is safe.

\section{Step 11: Check for bending stress}

From PSG data book, Page no. 8.44,

$\sigma_{\mathrm{b}}=\frac{1.9 \times\left[M_{t}\right]}{m_{x}{ }^{3} \times q \times z \times y_{v}}$

From PSG data book,

$$
y_{v}=0.590
$$




$$
\begin{aligned}
& \sigma_{b}=\frac{1.9 \times\left[159.17 \times 10^{\wedge} 3\right]}{5^{3} \times 11 \times 60 \times 0.59} \\
& \sigma_{b}=15.61 \mathrm{~N} / \mathrm{mm}^{2}
\end{aligned}
$$

Here, induced $\sigma_{\mathrm{b}}<$ allowable $\left[\sigma_{\mathrm{b}}\right]$

Design is safe.

\section{Step 12: Find the efficiency}

From PSG data book, Page no. 8.49,

$$
\begin{aligned}
& \eta=\frac{\tan \gamma}{\tan (\gamma+p)} \\
& \mu=\tan p \\
& 0.3=\tan p \\
& p=1.718 \\
& \tan \gamma=\frac{z}{q}=\frac{3}{11}, \gamma=15.25 \\
& \eta=\frac{\tan 15.25}{\tan (15.25+1.718)} \\
& \eta=89.3 \%
\end{aligned}
$$

\section{Step 13: Heat thermal analysis}

$$
\begin{aligned}
\mathrm{Hg} & =(1-\eta) \times \mathrm{I} . \mathrm{P} \\
& =(1-0.893) \times 1 \\
& =1070 \mathrm{~W} \\
= & \mathrm{Hd} \\
\mathrm{Hd} & =\mathrm{h} \times \mathrm{A} \times \Delta t \\
1070= & 10 \times \mathrm{A} \times 50 \\
\mathrm{~A}= & 2.675 \mathrm{~m}^{2}
\end{aligned}
$$

\subsection{Design of Cylinder Holder}

Volume of cylinder holder $=$ volume of cuboid - volume of cylindrical hole

Volume of cuboid $=1 \times b \times h$

$$
\begin{aligned}
& =80 \times 100 \times 90 \\
& =720000 \mathrm{~mm}^{3}
\end{aligned}
$$

Volume of cylinder hole $=(\pi / 5) \times \mathrm{d}^{2} \times 1$

$$
\begin{aligned}
& =(\pi / 5) \times 60^{2} \times 90 \\
& =255569 \mathrm{~mm}^{3}
\end{aligned}
$$

Volume of cylinder holder $=720000-255569$

$$
=565531 \mathrm{~mm}^{3}
$$

Mass of cylinder holder $=$ Volume of cylinder holder $\times$ density

$$
\begin{aligned}
& =565531 \times 7.85 \times 10^{-6} \\
& =3.65 \mathrm{~kg}
\end{aligned}
$$

Force $=$ mass $\times$ acceleration

$$
\begin{aligned}
& =3.65 \times 9.81 \\
& =35.81 \mathrm{~N}
\end{aligned}
$$




\subsection{Design of Spring}

$\mathrm{d}_{\mathrm{l}}=15 \mathrm{~mm}, \quad \mathrm{P}_{\mathrm{r}}=1.2 \mathrm{~N} / \mathrm{mm}^{2}$

Maximum lift, $\mathrm{y}=10 \mathrm{~mm}$

Spring index, $\mathrm{C}=5$

Initial compression, $\mathrm{y}_{\mathrm{i}}=20 \mathrm{~mm}$

$\tau=550 \mathrm{~N} / \mathrm{mm}^{2}, \quad \mathrm{G}=0.8 \times 10^{5} \mathrm{~N} / \mathrm{mm}^{2}$

\section{Step 1: Find the area of the rod}

$$
\begin{aligned}
\mathrm{A}_{\mathrm{r}} & =(\pi / 5) \times \mathrm{d}_{\mathrm{r}}^{2} \\
& =(\pi / 5) \times 15^{2} \\
& =176.71 \mathrm{~mm}^{2}
\end{aligned}
$$

\section{Step 2: Find the Wahl stress factor}

From PSG data book, Page no. 7.100,

$$
\begin{aligned}
& \mathrm{K}_{\mathrm{s}}=\frac{5 C-1}{5 C+1}+\frac{0.615}{C} \\
& =\frac{(5 \times 5)-1}{(5 \times 5)+1}+\frac{0.615}{5} \\
& =1.31
\end{aligned}
$$

Step 3: Find the maximum pressure

$$
\begin{aligned}
\mathrm{P}_{\max }= & \mathrm{P}_{\mathrm{i}} \times \frac{y_{\max }}{y_{i}} \\
y_{\text {max }}= & \mathrm{y}_{\mathrm{i}}+\mathrm{y} \\
= & 10+20 \\
= & 30 \mathrm{~mm} \\
\mathrm{P}_{\mathrm{i}}= & \mathrm{P}_{\mathrm{r}} \times \mathrm{A}_{\mathrm{r}} \\
= & 1.2 \times 176.71 \\
= & 212.05 \mathrm{~N} \\
\mathrm{P}_{\max }= & 212.05 \times \frac{30}{20} \\
= & 318.08 \mathrm{~N}
\end{aligned}
$$

Step 4: Find the diameter of the wire

From PSG data book, Page no. 7.100,

$$
\begin{aligned}
\tau=\mathrm{K}_{\mathrm{s}} \times \frac{8 P_{\max } C}{\pi d^{2}} \\
550=\frac{1.31 \times 8 \times 318.05 \times 5}{\pi d^{2}} \\
\mathrm{~d}=3.53 \mathrm{~mm}
\end{aligned}
$$

From PSG data book, Page no. 7.20,

Standard wire diameter, $\mathrm{d}=3.55 \mathrm{~mm}$

Step 5: Find the mean diameter of the coil

$$
\begin{aligned}
& \mathrm{C}=\mathrm{D} / \mathrm{d} \\
& \mathrm{D}=\mathrm{d} \times \mathrm{C} \\
& =3.55 \times 5 \\
& \mathrm{D}=17.75 \mathrm{~mm}
\end{aligned}
$$




\section{Step 6: Find the number of active turns}

From PSG data book, Page no. 7.100,

$$
\begin{aligned}
y_{\text {max }} & =\frac{8 P_{\max } C^{3} n}{G d} \\
30 & =\frac{8 \times 318.08 \times 5^{3} \times n}{G d} \\
\mathrm{n} & =26.78 \sim 27
\end{aligned}
$$

\section{Step 7: Find the pitch of the spring}

$$
\begin{aligned}
\mathrm{P} & =\mathrm{d}+\frac{y_{\max }}{n} \\
& =3.55+\frac{30}{27} \\
& =4.66 \mathrm{~mm}
\end{aligned}
$$

\subsection{Calculation of Cylinder Actuation Pressure}

\section{For clamp cylinder,}

Pressure required $=($ force $/$ area $)$

Calculated force $=92.7 \mathrm{~N}$

Taking maximum force $=95 \mathrm{~N}$

$$
\begin{aligned}
\text { Area }=(\pi / 5) d^{2} & \\
& =(\pi / 5) \times 35^{2} \\
& =962.11 \mathrm{~mm}^{2}
\end{aligned}
$$

Required pressure $=(95 / 962.11)$

$=0.98 \mathrm{bar}$

\section{For tool cylinder,}

Pressure required $=($ force $/$ area $)$

Calculated force $=162.7 \mathrm{~N}$

Taking maximum force $=170 \mathrm{~N}$

$$
\begin{aligned}
\text { Area } & =(\pi / 5) d^{2} \\
& =(\pi / 5) \times 50^{2} \\
& =1256.6 \mathrm{~mm}^{2}
\end{aligned}
$$

Required pressure $=(170 / 1256.6)$

$$
=1.35 \mathrm{bar}
$$

\section{For stopper cylinder,}

Pressure required $=($ force $/$ area $)$

Calculated force $=21.92 \mathrm{~N}$

Taking maximum force $=25 \mathrm{~N}$

$$
\begin{aligned}
\text { Area } & =(\pi / 5) d^{2} \\
& =(\pi / 5) 25^{2} \\
& =590.87 \mathrm{~mm}^{2} \\
\text { Required pressure } & =(25 / 590.87) \\
& =0.5 \mathrm{bar}
\end{aligned}
$$

\subsection{Design of Stopper Fixture}

Volume of stopper fixture $=(2 \times$ volume of circular rod $)+$ volume of rectangle box

Volume of circular $\operatorname{rod}=(\pi / 5) d^{2} 1$

$$
\begin{aligned}
& =(\pi / 5) \times \mathrm{d}^{2} \times 300 \\
& =23561.9 \mathrm{~mm}^{3}
\end{aligned}
$$




$$
\begin{aligned}
& \text { Volume of rectangle box }=1 \times \mathrm{b} \times \mathrm{h} \\
& \qquad \begin{aligned}
& \\
& =15000 \mathrm{~mm}^{3} \\
& =150 \times 25
\end{aligned}
\end{aligned}
$$

Volume of stopper rod $=(2 \times 23561.9)+15000$

$$
=62123.88 \mathrm{~mm}^{3}
$$

Mass of stopper fixture $=$ volume $\times$ density

$$
\begin{aligned}
& =62123.88 \times 7.85 \times 10^{-6} \\
= & 0.58 \mathrm{~kg} \\
\text { Force }= & \text { mass } \times \text { acceleration } \\
= & 0.58 \times 9.81 \\
= & 5.72 \mathrm{~N}
\end{aligned}
$$

\section{Modeling of Machine ANd MACHINE CoMponents}

The 3-D modeling of machine and the components is carried out in Solid Works software. The modeling application also provides "features based" solid bodies by directing editing capabilities, which allow changing and updating solid bodies by directing editing the dimensions of a solid feature or by other geometric construction techniques.

\subsection{Isometric View of Counter Sinking Machine}

The isometric view of the counter sinking machine is illustrated in Figure 1

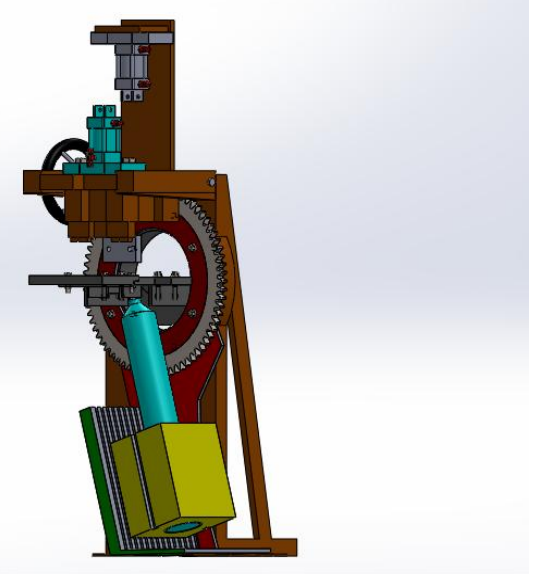

Figure1. Isometric View of Counter sinking machine

\subsubsection{Modeling of Cylinder Support Plate and Worm Gear}

The modeling of cylinder support plate and worm gear is depicted in Figures 2 and 3.

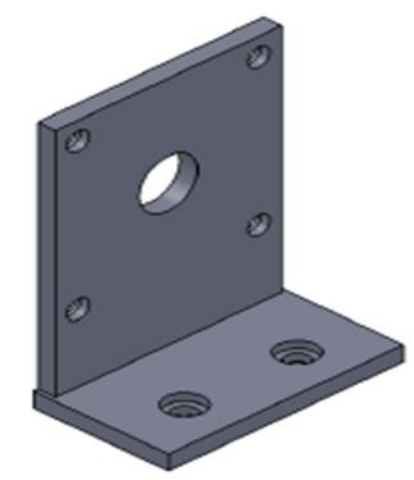

Figure2. Isometric View of cylinder support plate 


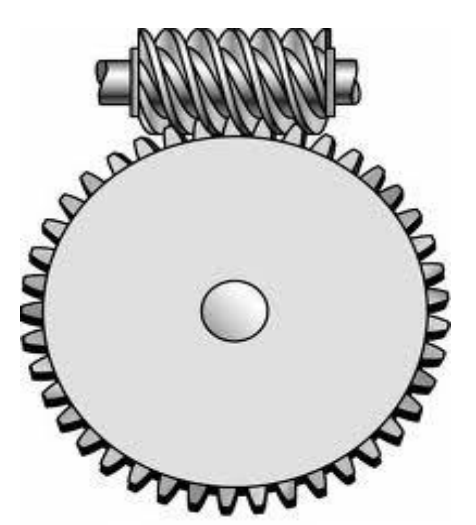

Figure3. Isometric View of worm gear

\subsection{Clamp Cylinder and Spring}

The isometric view of clamp cylinder and spring is depicted in Figures 4 and 5.The Figure 6 and 7 show the isometric view of tool cylinder and cylinder holder.

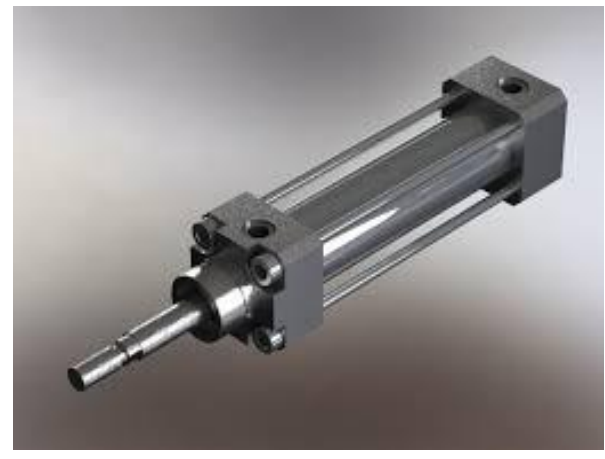

Figure4. Isometric View of clamp cylinder

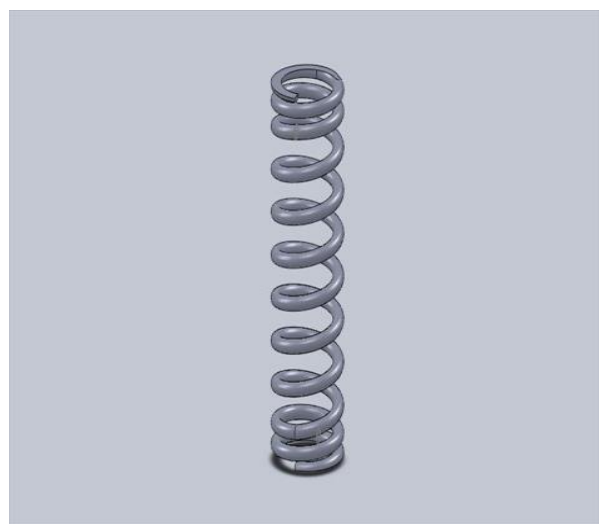

Figure5. Isometric View of spring

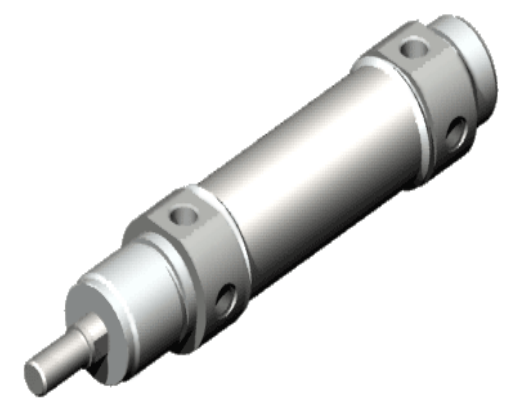

Figure6. Isometric View of tool cylinder 


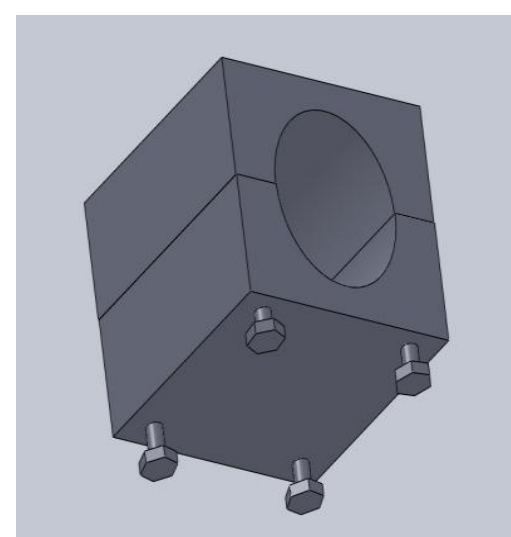

Figure7. Isometric View of cylinder holder

\section{Working METHOdology OF THE FABRiCATEd Machine}

Countersinking machine is connected with the hole piercing machine. In hole piercing machine, the work piece is feed by the worker. After the hole is pierced, the work piece is allowed to enter the countersinking machine for countersink. Initially, we switch on the supply. The supply is given to the tool cylinder. The availability of the work piece is sensed by the work piece sensor. After that, the clamp is down and clamps the work piece. The clamping is sensed by the clamp down sensor. Then, the spindle comes forward and it is sensed by the spindle forward sensor. While the spindle moves forward, the stopper cylinder is actuated. The actuation of stopper cylinder is sensed by the stopper sensor. Therefore, the clamp is up. So, the work piece is released from the clamp and goes to the storage tank through the tray. The exit of the work piece is sensed by the exit sensor. After the signal is sensed, this cycle is again repeated.

The front and side view of the fabricated counter sinking machine is depicted in figures 8 and 9 .

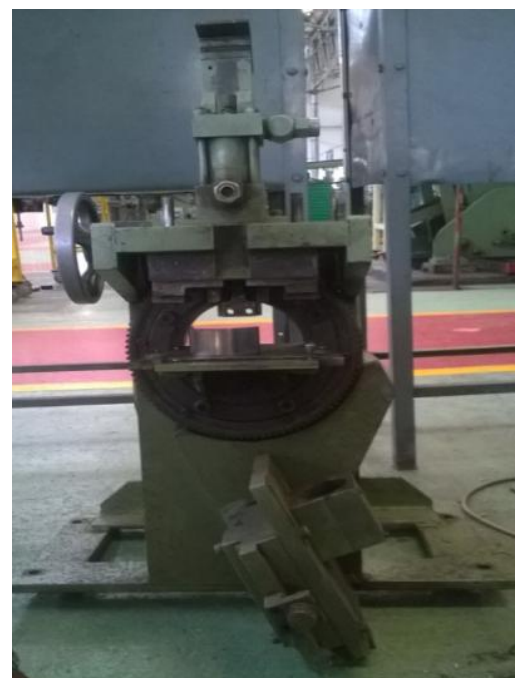

Figure9. Front view of the machine

\section{RELAY LOGIC DIAGRAM}

This diagram is helpful for the automation purpose. For this paper the below figure 10 is used to construct for the automation of counter sinking machine.

Where,

$\mathrm{S}_{1}-$ Work piece available sensor (Laser sensor) $\mathrm{S}_{2}-$ Clamp down sensor

$\mathrm{S}_{3}-$ Spindle forward sensor $\mathrm{S}_{4}-$ Stopper up sensor $\mathrm{S}_{5}-$ Exit sensor

$\mathrm{C}, \mathrm{C}_{3}-8$ Pin 25V Relay $\quad \mathrm{C}_{1}, \mathrm{C}_{2}, \mathrm{C}_{4}, \mathrm{C}_{5}-5$ Pin Relay

$\mathrm{PB}_{1}-$ Emergency stop $\quad \mathrm{PB}_{2}-$ Switch $\mathrm{ON} \quad \mathrm{PB}_{3}-$ Cycle start

$1,2,3,4,5$.

15 - Wire number

International Journal of Modern Studies in Mechanical Engineering (IJMSME)

Page | 15 


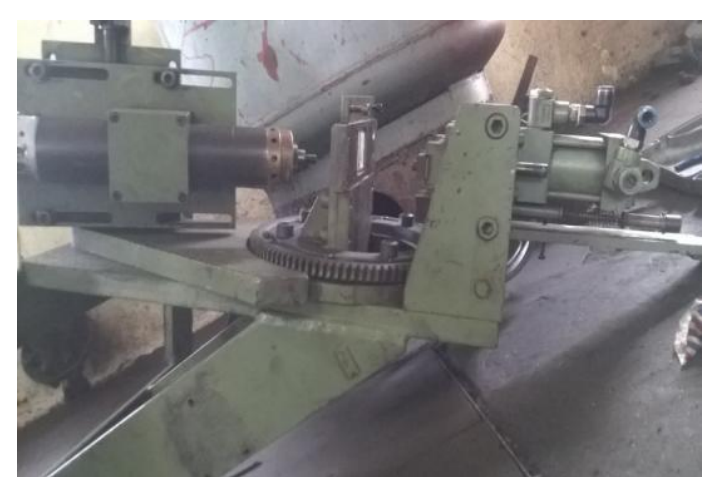

Figure10. Side view of the machine

\section{Productivity Calculation}

\subsection{Before Automation}

Number of products per hour $=120$ numbers

For 2 shifts per day $\quad=8$ hours $\times 2 \times 120$

$$
=1920 \text { numbers }
$$

Total productivity per month $=25 \times 1920$

$$
=48,000 \text { numbers }
$$

\subsection{After Automation}

$$
\begin{array}{cl}
\text { Number of products per hour } & =157 \text { numbers } \\
\text { For } 2 \text { shifts per day } & =8 \text { hours } \times 2 \times 200 \\
= & 3200 \text { numbers }
\end{array}
$$

Total productivity per month $=25 \times 3200$

$$
=80,000 \text { numbers }
$$

Increase in number of products per month $=32,000$ numbers

$$
\begin{array}{cc}
\text { Conversion cost for } 1 \text { component } & =\text { Rs. } 1.00 \\
\text { Savings } / \text { Month } & =32000 \times 1 \\
& =\text { Rs.32,000/month } \\
\text { Savings } / \text { Year } & =\text { Rs.3,85,000/Year }=\text { Rs.3.85 Lacs } / \text { Year }
\end{array}
$$

\section{CONCLUSION}

From this paper the fabricated automatic counter sinking machine takes less time to manufacture components when compared to conventional counter sinking machine. The production rate will also be increased in this machine when compared to the conventional machine. The cost of the product is less by producing this product by automatic counter sinking machine.

\section{REFERENCES}

[1] Krishnaraj V, Zitoune R, Collombet F (2010) Comprehensive review on drilling of multimaterial stacks. J Mach Forming Technol 2:171-200.

[2] Gao Y, Wu D, Nan C, Chen K (2015) Normal direction measurement in robotic drilling and precision calculation. Int J Adv Manuf Technol 76:1311-1318.

[3] Sanda A, Arriola I, Navas VG, Bengoetxea I, Gonzalo O (2016) ultrasonically assisted drilling of carbon fibre reinforced plastics and Ti6Al4V. J Manuf Process 22:169-176.

[4] Dahnel AN, Ascroft H, Barnes S (2016) The effect of varying cutting speeds on tool wear during conventional and ultrasonic assisted drilling (UAD) of carbon fibre composite (CFC) and titanium alloy stacks. Procedia CIRP 46:420-423.

[5] Schroeder PT (1998) Widening interest in twist drill. Modern Mach Shop 71:106-113. 
[6] Fei SH, Qiang F, Meng XL, Ying-Lin KE (2012) Countersink depth control of robot drilling based on pressure foot displacement compensation. J Zhejiang Univ 46:1157-1161.

[7] Ma X, Wu D, Gao Y, Liang X, Huang S, Dong Y (2017) An approach to countersink depth control in the drilling of thin-wall stacked structures with low stiffness. Int J Adv Manuf Technol 95(1-4): 78579.

[8] Richard G. Budynas( 2008), Mechanical Engineering Design, Tat McGraw-Hill India Pvt Ltd, New Delhi.

[9] Cheng H, Zhang K, Wang N, Luo B, Meng Q (2017) A novel six-state cutting force model for drillingcountersinking machining process of CFRP-Al stacks. Int J Adv Manuf Technol 89(5-8):2063-2076.

[10] Wang DH, Ramulu M, Arola D (1995) Orthogonal cutting mechanisms of graphite/epoxy composite. Part i: unidirectional laminate. Int J Mach Tool Manu 35(12):1623-1638.

[11] Liang X, Wu D, Gao Y, Chen K (2018) Investigation on the non-coaxiality in the drilling of carbon-fibrereinforced plastic and aluminium stacks. Int J Mach Tool Manu 125:1-10.

[12] Qi Z, Zhang K, Cheng H, Wang D, Meng Q (2015) Microscopic mechanism based force prediction in orthogonal cutting of unidirectional CFRP. Int J Adv Manuf Technol 79(5-8):1209-1219.

[13] Lance Nelson, (2007) Spring loaded tool with floating depth control for countersink holes. U.S. patent 7607871B1. 593, pp.29-35.

[14] Johnson, Harry M (2005) Countersink cutters a book- Vol 20, pp.175-187.

[15] Zhang LC (2009) Cutting composites: a discussion on mechanics modelling. J Mater Process Technol 209(9):4548-4552.

Citation: Dr. M. K. Marichelvam, Mr. K.Kandakodeeswaran, (2019)" Design and Fabrication of Automated Countersinking Machine”, International Journal of Modern Studies in Mechanical Engineering, 5(2), pp. 6-17. DOI: http://dx.doi. org/10.20431/2454-9711.0502002

Copyright: (c) 2019 Authors, This is an open-access article distributed under the terms of the Creative Commons Attribution License, which permits unrestricted use, distribution, and reproduction in any medium, provided the original author and source are credited. 